As-Syifaa Jurnal Farmasi Desember 2020;12(2):107-116.

ISSN : 2502-9444 (electronic); 2085-4714 (printed)

Journal Homepage : http://jurnal.farmasi.umi.ac.id/index.php/as-syifaa

\title{
IDENTIFIKASI MEDICATION ERROR PADA RESEP PASIEN PEDIATRI di PALU INDONESIA
}

\author{
Firdayanti, Amelia Rumi
}

Jurusan Farmasi, Universitas Tadulako, Palu

Email: firdayanti230898@gmail.com

\begin{abstract}
Medication error is an event that is detrimental to the patient and can also endanger the safety of the patient, occurring as long as the patient is in a preventable health care workforce. This research aims to determine the form and percentage of medication error on prescription pediatric patients aged 2 months - 18 years in one of the hospitals in the city of Palu, Indoenesia. This research is a descriptive cross-sectional research with data retrieval conducted prospectively with the total sampling method. The sample of this study has 118 prescription paediatric patients in the period of September to October 2019. With the results of the research medication error in the prescribing phase ie no SIP doctor $92.37 \%$, no high patients $92.37 \%$, no weight $90.67 \%$, no age of the patient $72.88 \%$, no medical record number $64.40 \%$, no dosage form 58.47. Phase of transcribing error is no patient status $81.65 \%$, no age of the patient $72.88 \%$, no apparent medical record number $59.32 \%$, not clear the dosage form of $53.38 \%$. The dispensing error is a $61.86 \%$ incorrect or incomplete tag. The administration error phase of the patient is not given an explanation about the cure $66.10 \% \%$, it can be concluded that it has been medication error in one of the hospitals in the city of Palu, Indonesia.
\end{abstract}

Key words: Medication Error, Prescribing, Transcribing, Dispensing, Administration.

\section{PENDAHULUAN}

Kesalahan pengobatan atau medication error adalah peristiwa yang dapat dicegah yang dapat menyebabkan atau mengarah pada penggunaan obat yang tidak tepat atau membahayakan pasien saat obat berada dalam kendali profesional perawatan kesehatan, pasien, atau konsumen. Kesalahan pengobatan dapat berupa kesalahan penulisan resep oleh dokter, kesalahan pembacaan resep oleh apoteker, kesalahan penyiapan obat oleh apoteker, dan kesalahan pemberian obat oleh apoteker. ${ }^{1}$

Medication error merupakan kejadian yang merugikan pasien akibat penanganan yang dilakukan oleh tenaga kesehatan (human error) yang sebetulnya dapat dicegah. ${ }^{2}$ Kesalahan pada salah satu tahap dapat terjadi secara berantai dan menimbulkan kesalahan pada tahap selanjutnya. ${ }^{3}$ Medication error dapat timbul pada setiap tahap proses pengobatan, antara lain prescribing (peresepan), transcribing (penerjemahan resep), dispensing (penyiapan obat) dan administration. ${ }^{4}$

Hasil World Population Data Sheet 2013 menggambarkan populasi anak di bawah umur 15 tahun di dunia mencapai 50\% dari keseluruhan jumlah populasi. ${ }^{5}$ Pasien anak merupakan pasien yang memiliki jalur administrasi obat yang begitu banyak. Banyaknya sediaan racikan yang diperoleh pediatri dapat meningkatkan risiko terjadinya medication error karena banyaknya potensi risiko di dalam proses meracik atau compounding. ${ }^{6}$

Hasil penelitian identifikasi medication error yang terjadi pada tahap prescribing resep pasien rawat jalan di Poli Interna RSUD Bitung yaitu tulisan resep tidak terbaca atau tidak 
jelas, tidak ada bentuk sediaan, tidak ada dosis sediaan, tidak ada umur pasien. Persentase medication error yang terjadi pada tahap prescribing yaitu tidak ada bentuk sediaan $74,53 \%$, tidak ada dosis sediaan $20,87 \%$, tidak ada umur pasien $62,87 \%$, tulisan resep tidak terbaca atau tidak jelas $6,50 \%$, dan berpotensi terjadinya medication error. ${ }^{3}$

Dalam penelitian ${ }^{7}$ menunjukkan bahwa hasil analisis medication error fase prescribing pada resep pasien anak rawat jalan di Instalasi Farmasi RSUD Sambas tahun 2014 sering terjadi pada administrasi resep yang tidak lengkap meliputi (tidak adanya tanggal penulisan resep, paraf dokter, alamat pasien, berat badan pasien dan jenis kelamin pasien), penulisan aturan pakai yang tidak jelas, dan penggunaan singkatan yang tidak lazim.

Berdasarkan latar belakang diatas, Medication error merupakan hal yang penting yang sering terjadi. Medication error sebenarnya dapat dihindari. Oleh karena itu, maka peneliti ingin melakukan identifikasi Medication error pada resep pasien pediatrik di salah satu rumah sakit di kota Palu, Indonesia yang merupakan salah satu rumah sakit yang dipilih sebagai tempat penelitian.

\section{METODE PENELITIAN}

Penelitian yang akan digunakan dalam Penelitian ini merupakan penelitian potong lintang (cross sectional) yang bersifat deskriptif karena hanya mengamati resep yang diberikan kepada pasien pediatrik. Dengan pengambilan data dilakukan secara prospektif. Sampel penelitian ini adalah resep pasien pediatri di salah satu Instalasi Farmasi Rawat Jalan rumah sakit di kota Palu, Indonesia pada periode September sampai Oktober 2019 yaitu sebanyak 118 resep. Variabel penelitian dalam penelitian ini yaitu medication error dengan melihat fase prescribing, fase transcribing, fase dispensing dan administration pada resep pasien pediatrik. Analisis data dilakukan secara kuantitatif dan diperoleh dengan cara mengolah hasil dan menghitung persentasi jumlah ketidaksesuaian pada tiap kategori kejadian medication error yaitu fase prescribing, fase transcribing, fase dispensing dan fase administration dari total resep pasien pediatri yang telah diamati. Standar untuk adanya kesalahan pemberian obat berkisar $100 \%$.

$\%$ ME $=\frac{\text { Jumlah Ketidaksesuaian Pada Tiap Kategori }}{\text { Jumlah Total Resep }} \times 100 \%$

\section{HASIL DAN PEMBAHASAN}

Hasil Penelitian secara prospektif ini dilakukan terhadap 118 resep pasien pediatri dengan umur 2 bulan-18 tahun di salah satu Instalasi Farmasi Rawat Jalan rumah sakit di kota Palu, Indonesia pada bulan SeptemberOktober 2019. Melalui metode pengambilan sampel secara total random dengan hasil pengamatan sampel berupa resep yang telah diolah dan kemudian dilakukan analisis deskriptif, maka dapat diketahui persentase medication error pada fase prescribing, fase transcribing, fase dispensing dan fase administration. Dari tabel 1. terlihat bahwa resep pasien anak yang dianalisis cenderung lebih banyak berjenis kelamin perempuan $56,78 \%$ dibandingkan laki-laki 43,22\% dikarenakan adanya perbedaan status gizi antara anak perempuan dan anak laki-laki yang disebabkan karena perbedaan pola aktvitas fisik anak dan jaringan penyusun tubuh, umumnya pada anak lai-laki lebih aktif. Sedangkan berdasarkan rentang umur pasien anak diperoleh umur 12-18 tahun merupakan yang paling tinggi jumlahnya yaitu $50,84 \%$, selanjutnya diikuti rentang umur 2-12 tahun yaitu $33,05 \%$ dan rentang umur 2 bulan-2 tahun 
yaitu $16,11 \%$. Adapun lima poli yang paling banyak memiliki pasien anak yaitu poli anak sebesar $36,44 \%$ dikarenakan pada poli anak melihat gangguan pertumbuhan dan perkembangan yang terjadi pada usia anak-

Tabel I. Data Karakteristik Pasien Anak anak, selanjutnya poli orthopedi sebesar $20,33 \%$, poli penyakit dalam sebesar $9,32 \%$, poli bedah saraf sebesar $6,78 \%$ dan poli THT$\mathrm{KL}$ sebesar $5,08 \%$.

\begin{tabular}{clcc}
\hline \multicolumn{1}{c}{ Karakteristik } & & $\mathbf{n = 1 1 8}$ \\
\cline { 2 - 3 } No. & Jenis Kelamin & Jumlah & Persentase (\%) \\
\hline Laki laki & 51 & $43,22 \%$ \\
& Perempuan & 67 & $56,78 \%$ \\
& Umur & & \\
2 bulan - 2 tahun & & $16,11 \%$ \\
2 tahun - 12 tahun & 19 & $33,05 \%$ \\
12 tahun - 18 tahun & 39 & $50,84 \%$ \\
Poli & 60 & \\
Penyakit Dalam & & \\
THT-KL & 11 & $9,33 \%$ \\
Bedah Saraf & 6 & $5,08 \%$ \\
Orthopedi & 8 & $6,78 \%$ \\
Gigi Bedah Mulut & 24 & $20,33 \%$ \\
Mata & 2 & $1,70 \%$ \\
Saraf & 3 & $2,54 \%$ \\
Anak & 2 & $1,70 \%$ \\
Bedah & 43 & $36,44 \%$ \\
Kulit Kelamin & 5 & $4,32 \%$ \\
Jantung dan Pembuluh Darah & 2 & $1,70 \%$ \\
Obgyn & 4 & $3,39 \%$ \\
Urologi & 3 & $2,54 \%$ \\
Rehabilitas Medik & 2 & $1,70 \%$ \\
Bedah Tulang dan Sendi & 1 & $0,85 \%$ \\
Jiwa & 1 & $0,85 \%$ \\
& 1 & $0,85 \%$ \\
\hline
\end{tabular}

Dari hasil penelitian yang dilakukan di salah satu Instalasi Farmasi Rawat Jalan Rumah Sakit di kota Palu, Indonesia alur perjalanan resep di mulai dari pasien bertemu dengan dokter, kemudian dokter akan melakukan pemeriksaan (diagnosis) serta memberikan terapi dan menuliskan resep pada penulisan resep tersebut bisa terjadi prescribing error (kesalahan dalam peresepan), berdasarkan hasil diagnosa kemudian resep diberikan kepada pasien yang bersangkutan, selanjutnya pasien akan menebus resep tersebut di instalasi farmasi rawat jalan undata palu kemudian pasien akan diberikan nomor antrian, resep akan diterima oleh apoteker atau tenaga teknis kefarmasian. Dan setelah itu petugas kefarmasian akan menerjemahkan resep tersebut, pada proses tersebut bisa terjadi kesalahan pada tahap transcribing error (kesalahan dalam penerjemahan) dan setelah menerjemahkan resep tersebut apoteker atau asisten apoteker akan menyiapkan dan meracik obat kemudian obat diberikan ke apoteker untuk diperiksa kembali, agar memperkecil kemungkinan terjadinya kesalahan pada tahap dispensing error (penyiapan obat). Setelah diperiksa kembali,obat diberikan ke pasien oleh 
apoteker, pada proses tersebut bisa terjadi yang dapat menyebabkan kesalahan pada kesalahan dimana pasien tidak diberikan tahap administration error.

informasi mengenai obat yang dikomsumsinya

Tabel 2. Data Analisis Identifikasi Medication Error Pada Fase Prescribing Error

\begin{tabular}{|c|c|c|c|}
\hline NO & Parameter & Jumlah Resep & Persentase (\%) \\
\hline 1 & $\begin{array}{l}\text { Tidak ada nama dokter penulis resep } \\
\text { Ada } \\
\text { Tidak ada }\end{array}$ & $\begin{array}{l}21 \\
97\end{array}$ & $\begin{array}{l}17,79 \\
82,21\end{array}$ \\
\hline 2 & $\begin{array}{l}\text { Tidak ada SIP dokter } \\
\text { Ada } \\
\text { Tidak ada }\end{array}$ & $\begin{array}{c}109 \\
9\end{array}$ & $\begin{array}{c}92,37 \\
7,63\end{array}$ \\
\hline 3 & $\begin{array}{l}\text { Tidak ada status dokter } \\
\text { Ada } \\
\text { Tidak ada }\end{array}$ & $\begin{array}{l}50 \\
68\end{array}$ & $\begin{array}{l}42,37 \\
57,63\end{array}$ \\
\hline 4 & $\begin{array}{l}\text { Tidak ada paraf dokter } \\
\text { Ada } \\
\text { Tidak ada }\end{array}$ & $\begin{array}{c}7 \\
111\end{array}$ & $\begin{array}{c}5,93 \\
94,07\end{array}$ \\
\hline 5 & $\begin{array}{l}\text { Tidak ada nama pasien } \\
\text { Ada } \\
\text { Tidak ada }\end{array}$ & $\begin{array}{l}26 \\
92\end{array}$ & $\begin{array}{l}22,03 \\
77,97\end{array}$ \\
\hline 6 & $\begin{array}{l}\text { Tidak ada nomor rekam medik } \\
\text { Ada } \\
\text { Tidak ada }\end{array}$ & $\begin{array}{l}76 \\
42\end{array}$ & $\begin{array}{l}64,40 \\
35,60\end{array}$ \\
\hline 7 & $\begin{array}{l}\text { Tidak ada usia pasien } \\
\text { Ada } \\
\text { Tidak ada }\end{array}$ & $\begin{array}{l}86 \\
32\end{array}$ & $\begin{array}{l}72,88 \\
27,12\end{array}$ \\
\hline 8 & $\begin{array}{l}\text { Tidak ada jumlah pemberian obat } \\
\text { Ada } \\
\text { Tidak ada }\end{array}$ & $\begin{array}{c}0 \\
118\end{array}$ & $\begin{array}{c}0 \\
100\end{array}$ \\
\hline 9 & $\begin{array}{l}\text { Tidak ada aturan pakai } \\
\text { Ada } \\
\text { Tidak ada }\end{array}$ & $\begin{array}{c}0 \\
118\end{array}$ & $\begin{array}{c}0 \\
100\end{array}$ \\
\hline 10 & $\begin{array}{l}\text { Tidak ada satuan dosis } \\
\text { Ada } \\
\text { Tidak ada }\end{array}$ & $\begin{array}{l}44 \\
74\end{array}$ & $\begin{array}{l}37,28 \\
62,72\end{array}$ \\
\hline 11 & $\begin{array}{l}\text { Tidak ada bentuk sediaan } \\
\text { Ada } \\
\text { Tidak ada }\end{array}$ & $\begin{array}{l}69 \\
49\end{array}$ & $\begin{array}{l}58,47 \\
41,52\end{array}$ \\
\hline 12 & $\begin{array}{l}\text { Tidak ada nama obat } \\
\text { Ada } \\
\text { Tidak ada } \\
\text { Tidak ada tanggal permintaan resep }\end{array}$ & $\begin{array}{c}0 \\
118\end{array}$ & $\begin{array}{c}0 \\
100\end{array}$ \\
\hline 13 & $\begin{array}{l}\text { Ada } \\
\text { Tidak ada } \\
\text { Tidak ada berat badan pasien }\end{array}$ & $\begin{array}{l}44 \\
74\end{array}$ & $\begin{array}{l}37,28 \\
62,72\end{array}$ \\
\hline 14 & $\begin{array}{l}\text { Ada } \\
\text { Tidak ada }\end{array}$ & $\begin{array}{c}107 \\
11\end{array}$ & $\begin{array}{c}90,67 \\
9,33\end{array}$ \\
\hline
\end{tabular}




\begin{tabular}{llcc}
\hline NO & \multicolumn{1}{c}{ Parameter } & Jumlah Resep & Persentase (\%) \\
\hline \multicolumn{1}{r}{} & Tidak ada tinggi pasien & & \\
\multirow{2}{*}{15} & Ada & 109 & 92,37 \\
& Tidak ada & 9 & 7,63 \\
& & & \\
& Tidak ada jenis kelamin & 17 & 14,40 \\
16 & Ada & 101 & 85,60 \\
\hline
\end{tabular}

Kemudian resep tersebut dinilai berdasarkan lembar kerja pengamatan medication error yang telah dibuat oleh peneliti pada fase prescribing error, transcribing error, dispensing error dan administration error pada resep pasien pediatri di salah satu Instalasi Farmasi Rawat Jalan Rumah Sakit Palu, Indonesia.

Berdasarkan Tabel 2. dari 118 resep yang dianalisis dapat diketahui hasil medication error pada fase prescribing tidak ada SIP dokter 92,37\%, tidak ada tinggi pasien 92,37\%, tidak ada berat badan 90,67\%, tidak ada usia pasien $72,88 \%$, tidak ada nomor rekam medik $64,40 \%$, tidak ada bentuk sediaan $58,47 \%$, tidak ada status dokter $42,37 \%$, tidak ada satuan dosis $37,28 \%$, tidak ada tanggal permintaan resep $37,28 \%$, tidak ada nama pasien $22,03 \%$, tidak ada nama dokter penulis resep $17,79 \%$, tidak ada jenis kelamin $14,40 \%$ dan tidak ada paraf dokter $5,93 \%$.

Data analisis identifikasi medication error pada fase prescribing dapat dilihat persentase kesalahan yang tinggi terjadi pada tidak ada SIP dokter 92,37\% (109 resep) dikarenakan ada beberapa dokter yang menyertakan SIP di stempelnya dan ada pula dokter yang sebaliknya, sehingga menyebabkan banyaknya tidak mencamtumkan SIP (Surat Izin Praktek) dalam menulis resep. Resep di salah satu Rumah Sakit di kota Palu, Indonesia tidak tercantum nomor izin praktek dokter hal ini dikarenakan dokter-dokter yang bekerja atau melakukan praktek di rumah sakit tersebut bernaung dibawah izin operasional rumah sakit. Dimana izin operasional rumah sakit adalah izin yang diberikan oleh pejabat yang bernaung sesuai kelas rumah sakit kepada penyelenggara/ pengelola rumah sakit untuk menyelenggarakan pelayanan kesehatan di rumah sakit setelah memenuhi persyaratan dan standar yang ditetapkan dalam Peraturan Menteri Kesehatan.

Kesalahan tidak ada nama dokter penulis resep $17,79 \%$ (21 resep) dan tidak ada paraf dokter 5,93\% (7 resep), pencantuman nama dan paraf dokter dalam resep juga merupakan hal yang penting untuk dicantumkan, jika terjadi kesalahan dalam hal peresepan maka petugas kefarmasian dapat langsung menghubungi dokter yang bersangkutan untuk melakukan verifikasi terkait dengan terapi obat yang diberikan kepada pasien. ${ }^{8}$ Tidak ada nama dokter memungkinkan besar resep ditulis oleh tenaga kesehatan lainnya, padahal menurut peraturan perundang-undangan yang berhak menulis resep adalah dokter, dokter gigi, dokter hewan kepada apoteker untuk menyediakan dan menyerahkan obat kepada pasien. Paraf dokter dalam resep merupakan salah satu parameter keabsahan suatu resep dan merupakan suatu bukti bahwa yang tertulis dalam resep adalah benar sesuai ilmu pengetahuan dan keahliannya. $^{9}$ 
Kesalahan tidak ada tanggal permintaan resep $37,28 \%$ (44 resep) dapat menyebabkan kesalahan pada resep pada saat penyiapan obat yang dilakukan oleh tenaga kefarmasiaan di apotek. Pemberian tanggal pada resep sangat penting untuk mengetahui kapan resep tersebut ditulis dan untuk menyiapkan obat yang diminta.

Kesalahan tidak ada nomor rekam medik $64,40 \%$ (76 resep), dapat menimbulkan kesalahan, karena dimungkinkan adanya nama pasien yang tidak dapat dibedakan atau sama, dan tidak ada status dokter $42,37 \%$ (50 resep) dapat berpotensi menyebabkan medication error, padahal pencantuman status dokter penulis resep ini juga sangat diperlukan, terutama bila terdapat hal-hal yang tidak jelas atau meragukan dalam resep yang perlu ditanyakan terlebih dahulu kepada penulis resep, sehingga memperlancar pelayanan obat di apotek.

Kesalahan tidak ada bentuk sediaan $58,47 \%$ (69 resep), tidak adanya bentuk sediaan ini sangat merugikan pasien. Pemilihan bentuk sediaan ini disesuaikan dengan kondisi dan kenyamanan pasien. Kemudian tidak ada satuan dosis 37,28\% (44 resep) merupakan bagian yang sangat penting dalam resep. Tidak adanya sangat berpeluang menimbulkan kesalahan oleh transcriber, hal ini karena beberapa obat memiliki dosis sediaan yang beragam. ${ }^{3}$

Kesalahan tidak ada nama pasien 22,03\% (26 resep) dapat menyebabkan kesalahan pada saat petugas farmasi ingin memberikan obat kepada pasien yang namanya tidak ada tertulis dalam resep, sehingga pasien tidak dapat meminum obat yang sudah diresepkan, tidak ada tinggi pasien 92,37\% (109 resep), tidak ada berat badan pasien 90,67\% (107 resep) dan tidak ada usia pasien $72,88 \%$ (86 resep) pada resep yang diteliti dapat berpotensi menyebabkan terjadinya medication error yang digunakan untuk mempertimbangkan dosis sediaan yang akan diberikan. Pentingnya pencantuman berat badan dan usia pasien dalam penulisan resep digunakan untuk menyebutkan bahwa berat badan merupakan salah satu aspek penting yang diperlukan dalam perhitungan dosis, khususnya dosis anak. Kondisi tubuh pasien tersebut bisa saja sangat berpengaruh terhadap terapi yang akan diberikan untuk pasien tersebut. Aspek kelengkapan resep yang paling banyak tidak tercantum dalam resep adalah berat badan pasien. Hal ini terjadi mungkin dikarenakan faktor kebiasaan dari dokter yang selalu tidak mencantumkan aspek berat badan pasien pada resep. Berat badan juga memiliki peran penting dalam suatu resep. Berat badan digunakan dalam penentuan dosis anak. Para ahli telah membuat rumus khusus berdasarkan berat badan seseorang.

Berdasarkan Tabel 3. dari 118 resep yang dianalisis dapat diketahui hasil medication error pada fase transcribing yaitu tidak ada status pasien $81,65 \%$, tidak ada usia pasien $72,88 \%$, tidak jelas nomor rekam medik $59,32 \%$, tidak jelas bentuk sediaan $53,38 \%$, tidak jelas nama obat $41,52 \%$, tidak ada tanggal permintaan resep $37,28 \%$, tidak jelas dosis pemberian $33,89 \%$ dan tidak jelas nama pasien $18,64 \%$.

Data analisis identifikasi medication error pada fase transcribing error dapat dilihat persentase Kesalahan yang tertinggi terjadi pada tidak ada status pasien $81,35 \%$ (96 resep), yang dapat menyebabkan tejadinya kesalahan pada bagian administrasi pada saat pasien ingin menebus obat, jika pasien kurang 
mampu diberikan obat paten akan dapat merugikan pasien tersebut. Kemudian tidak ada status pasien dalam resep membuat administrasi obat semuanya untuk pasien diberikan sama. Sedangkan menurut ${ }^{10}$ faktor yang menyebabkan tidak adanya status pasien didalam resep dikarenakan faktor kesibukan kerja akibat banyaknya jumlah pasien pada saat pemeriksaan identitas pasien, kesalahan pembacaan identitias pasien, dan resep yang tidak lengkap. Selanjutnya kesalahan yang terjadi pada penelitian ini yaitu tidak jelas nama pasien, tidak jelas nomor rekam medik, tidak ada usia pasien, tidak jelas nama obat, tidak ada dosis pemberian, tidak jelas bentuk sediaan, tidak ada tanggal permintaan resep disebabkan oleh karena penulisan resep yang tidak jelas atau tulisan dokter yang buruk. Tulisan dokter yang buruk dapat menyebabkan miskomunikasi antara dokter penulis resep dengan farmasis yang ada di apotek pada saat menerjemahkan resep. Penyebab-penyebab kesalahan yang terjadi antara lain kesalahan dalam membaca resep yang tidak lengkap, tidak mengikuti perintah yang ada diresep karena tulisan yang tidak jelas, dan intruksi yang dalam resep dilewatkan tanpa konsultasi langsung ke penulis resep (dokter).

Tabel 3. Data Analisis Identifikasi Medication Error Pada Fase Transcribing Error

\begin{tabular}{|c|c|c|c|}
\hline NO & Parameter & Jumlah Resep & Persentase (\%) \\
\hline 1 & $\begin{array}{l}\text { Tidak jelas nama pasien } \\
\text { Jelas } \\
\text { Tidak jelas }\end{array}$ & $\begin{array}{l}22 \\
96\end{array}$ & $\begin{array}{l}18,64 \\
81,36\end{array}$ \\
\hline 2 & $\begin{array}{l}\text { Tidak jelas nomor rekam medik } \\
\text { Jelas } \\
\text { Tidak jelas }\end{array}$ & $\begin{array}{l}70 \\
48\end{array}$ & $\begin{array}{l}59,32 \\
40,68\end{array}$ \\
\hline 3 & $\begin{array}{l}\text { Tidak ada usia pasien } \\
\text { Ada } \\
\text { Tidak ada }\end{array}$ & $\begin{array}{l}86 \\
32\end{array}$ & $\begin{array}{l}72,88 \\
27,12\end{array}$ \\
\hline 4 & $\begin{array}{l}\text { Tidak jelas nama obat } \\
\text { Jelas } \\
\text { Tidak jelas }\end{array}$ & $\begin{array}{l}49 \\
69\end{array}$ & $\begin{array}{l}41,52 \\
58,48\end{array}$ \\
\hline 5 & $\begin{array}{l}\text { Tidak jelas dosis pemberian } \\
\text { Jelas } \\
\text { Tidak jelas }\end{array}$ & $\begin{array}{l}40 \\
78\end{array}$ & $\begin{array}{l}33,89 \\
66,11\end{array}$ \\
\hline 6 & $\begin{array}{l}\text { Tidak jelas bentuk sediaan } \\
\text { Jelas } \\
\text { Tidak jelas }\end{array}$ & $\begin{array}{l}63 \\
55\end{array}$ & $\begin{array}{l}53,38 \\
46,62\end{array}$ \\
\hline 7 & $\begin{array}{l}\text { Tidak ada tanggal permintaan resep } \\
\text { Ada } \\
\text { Tidak ada }\end{array}$ & $\begin{array}{l}44 \\
74\end{array}$ & $\begin{array}{l}37,28 \\
62,72\end{array}$ \\
\hline 8 & $\begin{array}{l}\text { Tidak ada status pasien } \\
\text { Ada } \\
\text { Tidak ada }\end{array}$ & $\begin{array}{l}96 \\
22\end{array}$ & $\begin{array}{l}81,35 \\
18,65\end{array}$ \\
\hline
\end{tabular}

Berdasarkan Tabel 4. dari 118 resep yang dianalisis dapat diketahui hasil medication error pada fase dispensing yaitu pemberian etiket yang salah atau tidak lengkap $61,86 \%$ 
(73 resep). Berdasarkan penelitian sebelumnya yang dilakukan oleh ${ }^{11}$ di RS. Pondok Indah Jakarta menyatakan bahwa kejadian medication error pada fase dispensing yang paling banyak terdapat pada komponen penilaian salah mengambil obat dengan jumlah kejadian sebanyak 6 dengan presentase $1.50 \%$. Sedangkan pada penelitian yang dilakukan pada fase dispensing di instalasi farmasi rumah sakit undata Palu sudah cukup baik yang hanya terdapat kesalahan pada pemberian etiket yang tidak lengkap, karena pada saat penulisan etiket ada beberapa kolom yang tidak diisi dalam etiket akibat tidak adanya atau tidak jelas perintah yang ada dalam resep yang ditulis oleh dokter.

Tabel 4. Data Analisis Identifikasi Medication Error Pada Fase Dispensing Error

\begin{tabular}{|c|c|c|c|}
\hline No. & Parameter & Jumlah Resep & Persentase (\%) \\
\hline 1 & $\begin{array}{l}\text { Salah pengambilan obat } \\
\text { Terjadi } \\
\text { Tidak terjadi }\end{array}$ & $\begin{array}{c}0 \\
118\end{array}$ & $\begin{array}{c}0 \\
100\end{array}$ \\
\hline 2 & $\begin{array}{l}\text { Salah pasien } \\
\text { Terjadi } \\
\text { Tidak terjadi }\end{array}$ & $\begin{array}{c}0 \\
118\end{array}$ & $\begin{array}{c}0 \\
100\end{array}$ \\
\hline 3 & $\begin{array}{l}\text { Salah menghitung dosis } \\
\text { Terjadi } \\
\text { Tidak terjadi }\end{array}$ & $\begin{array}{c}0 \\
118\end{array}$ & $\begin{array}{c}0 \\
100\end{array}$ \\
\hline 4 & $\begin{array}{l}\text { Pemberian etiket yang tidak lengkap } \\
\text { Terjadi } \\
\text { Tidak terjadi }\end{array}$ & $\begin{array}{l}73 \\
45\end{array}$ & $\begin{array}{l}61,86 \\
38,14\end{array}$ \\
\hline 5 & $\begin{array}{l}\text { Obat kadaluarsa atau sudah rusak } \\
\text { Terjadi } \\
\text { Tidak terjadi }\end{array}$ & $\begin{array}{l}0 \\
118\end{array}$ & $\begin{array}{c}0 \\
100\end{array}$ \\
\hline 6 & $\begin{array}{l}\text { Obat ada yang kurang } \\
\text { Terjadi } \\
\text { Tidak terjadi }\end{array}$ & $\begin{array}{c}0 \\
118\end{array}$ & $\begin{array}{c}0 \\
100\end{array}$ \\
\hline 7 & $\begin{array}{l}\text { Tempat penyimpanan tidak tepat } \\
\text { Terjadi } \\
\text { Tidak terjadi }\end{array}$ & $\begin{array}{l}0 \\
118 \\
\end{array}$ & $\begin{array}{c}0 \\
100\end{array}$ \\
\hline
\end{tabular}

Data analisis identifikasi medication error pada fase dispensing error pada penelitian ini sudah cukup baik yang dibuktikan dengan hasil penelitian salah pengambilan obat, salah pasien, salah menghitung dosis, obat kadaluarsa atau sudah rusak, obat ada yang kurang dan tempat penyimpanan yang tidak tepat sudah tidak ada yang terjadi.

Salah pengambilan obat tidak terjadi karena di apotek obat disusun berdasarkan alfabet sehingga petugas farmasis mudah dalam pengambilan obat dan untuk obat yang mirip atau dengan tampilan yang mirip diberi tanda peringatan LASA (Look Alike Sound Alike) sehingga mengurangi resiko terjadi kesalahan. Kemudian tidak terjadinya salah pasien karena petugas farmasis memeriksa resep yang diberikan pasien sebelum dilayani untuk memperkecil risiko terjadinya kesalahan yang sebenarnya dapat dicegah oleh petugas 
farmasis. Kemudian tidak terjadi salah menghitung dosis karena petugas farmasis sudah mempunyai ilmu pengetahuan yang dimana petugas farmasi yang ada diapotek sudah bergelar sarjana farmasi dan sudah apoteker. Kemudian tidak terjadi pengambilan obat yang kadaluarsa atau sudah rusak dan obat ada yang kurang karena sebelum obat diberikan ke pasien obat yang sudah disiapkan tersebut diperiksa kembali oleh apoteker untuk mencegah terjadinya kesalahan yang dapat merugikan atau memperparah penyakit pasien akibat kelalaian yang dilakukan oleh tenaga farmasis di apotek.

Tabel 5. Data Analisis Identifikasi Medication Error Pada Fase Administration Error

\begin{tabular}{|c|c|c|c|}
\hline No. & Parameter & Jumlah Resep & Persentase (\%) \\
\hline 1 & $\begin{array}{l}\text { Salah dalam menyebut nama pasien } \\
\text { Terjadi } \\
\text { Tidak terjadi }\end{array}$ & $\begin{array}{c}16 \\
102\end{array}$ & $\begin{array}{l}13,55 \% \\
86,45 \%\end{array}$ \\
\hline 2 & $\begin{array}{l}\text { Salah pemberian obat pada pasien } \\
\text { Terjadi } \\
\text { Tidak terjadi }\end{array}$ & $\begin{array}{c}0 \\
118\end{array}$ & $\begin{array}{c}0 \\
100 \%\end{array}$ \\
\hline 3 & $\begin{array}{l}\text { Lupa memberikan obat pada pasien } \\
\text { Terjadi } \\
\text { Tidak terjadi }\end{array}$ & $\begin{array}{c}0 \\
118\end{array}$ & $\begin{array}{c}0 \\
100 \%\end{array}$ \\
\hline 4 & $\begin{array}{l}\text { Pasien tidak diberikan penjelasan tent } \\
\text { obatnya } \\
\text { Terjadi } \\
\text { Tidak teriadi }\end{array}$ & $\begin{array}{l}78 \\
40\end{array}$ & $\begin{array}{l}66,10 \% \\
33,89 \%\end{array}$ \\
\hline
\end{tabular}

Berdasarkan Tabel 5. dari 118 resep yang dianalisis dapat diketahui hasil medication error pada fase administration yaitu pasien tidak diberikan penjelasan tentang obatnya $66,10 \%$ dan salah dalam menyebut nama pasien $13,55 \%$.

Data analisis identifikasi medication error pada fase administration error pada hasil penelitian didapatkan kesalahan yanng sering terjadi yaitu pasien tidak diberikan penjelasan tentang obatnya $66,10 \%$ (78 resep) dan salah dalam menyebut nama pasien $13,55 \%$ (16 resep), dikarenakan beban kerja dilingkungan apotek yang terlalu ribut dan juga pasien yang ingin cepat pulang karena sudah lama menunggu antrian dari pagi mulai dari loket sampai menebus obat di apotek yang membuat petugas tidak memberikan penjelasan tentang obat yang dikomsumsi pasien. Menurut ${ }^{10}$ faktor kelalaian dan ketidaktelitian petugas menyebabkan administration error bagi pasien, kesibukan kerja akibat banyaknya jumlah pasien dapat menjadi faktor kelalaian petugas farmasis dan keluarga pasien yang kooperatif merupakan salah satu faktor yang menyebabkan terjadinya medication error.

Salah pemberian obat pada pasien tidak terjadi karena sebelum obat diberikan ke pasien obat tersebut diperiksa kembali oleh apoteker untuk mengecek agar obat tersebut sudah benar sesuai dengan yang ditulis dalam resep, kemudian lupa memberikan obat pada pasien tidak terjadi karena sesudah pasien memberikan resep kepada petugas di apotek langsung memberikan nomor antrian yang ada, karena pelayanan di apotek berdasarkan nomor antrian yang diberikan kepada pasien 
untuk menghindari kesalahan lupa memberikan obat pada pasien.

\section{KESIMPULAN}

Berdasarkan penelitian yang telah dilakukan dapat ditarik kesimpulan yaitu pada fase prescribing yaitu tidak ada SIP dokter $92,37 \%$, tidak ada tinggi pasien $92,37 \%$, tidak ada berat badan $90,67 \%$, tidak ada usia pasien $72,88 \%$, tidak ada nomor rekam medik $64,40 \%$, tidak ada bentuk sediaan 58,47. Fase transcribing error yaitu tidak ada status pasien $81,65 \%$, tidak ada usia pasien $72,88 \%$, tidak jelas nomor rekam medik $59,32 \%$, tidak jelas bentuk sediaan $53,38 \%$. Fase dispensing error yaitu pemberian etiket yang salah atau tidak lengkap $61,86 \%$. Fase administration error yaitu pasien tidak diberikan penjelasan tentang obatnya $66,10 \%$.

\section{DAFTAR PUSTAKA}

1. Kusuma I. Pakai "Maskara" Dan Jadilah Pasien Cerdas! Yogyakarta: Gadjah Mada University Press; 2017.

2. Hartati, Lolok, Herpianti N, Fudholi A, Satibi. Analisis Kejadin Medication Error Pada Pasien ICU. Fak Farm Univ Setia Budi, Surakarta Fak Farm Univ Gadjah Mada, Yogyakarta. 2014;4(2):125-132.

3. Timbongol C, Lolo WA, Sudewi S. Identifikasi Kesalahan Pengobatan (Medication Error) pada Tahap Peresepan (Prescribing) di Poli Interna. Progr Stud Farm FMIPA UNSRAT Manad. 2016;5(3):1-6.

https://ejournal.unsrat.ac.id/index.php/phar macon/article/view/12930.

4. Anonim. InfoPOM: Monitoring Efek
Samping Obat Sebagai Upaya Pencegahan Medication Error. Jakarta: Badan Pengawas Obat dan Makanan Republik Indonesia; 2015.

5. PopulationReferencesBureau. "World Population Data Sheet 2013. "http://www.prb .org/Publications/datasheets/2013-worldpopulations-data-sheet-/data-sheet.aspx. Diakses pada tanggal 22 mei 2019 pukul 16.45 WITA. Published 2013.

6. Gudeman J, Jozwiakowski M, Chollet J, Michael R. Potential risks of pharmacy compounding. Drugs R D. 2013;13(1):1-8.

7. Maiz N, Nurmainah, Untari, Eka K. Analisis Medication Error Fase Prescribing Pada Resep Pasien Anak Rawat Jalan di Instalasi Farmasi RSUD Sambas Tahun 2014. Progr Stud Farm Fak Kedokt Univ Tanjungpura. 2014:1-9.

8. Khairurrijal MAW, Putriana NA. Review: Medication Erorr Pada Tahap Prescribing, Transcribing, Dispensing, dan Administration. Farmasetika.com. 2018;2(4):8. doi:10.24198/farmasetika.v2i4.15020

9. Susanti I. Identifikasi Medication Error Pada Fase Prescribing, Transcribing, dan Dispensing di Depo Farmasi Rawat Inap Penyakit Dalam Gedung Teratai, Instalasi Farmasi RSUP Fatmawati Periode 2013. 2013.

10. Ismainar. Keselamatan Pasien Di Rumah Sakit. Yogyakarta: Deepublish Publisher; 2019.

11. Nilasari $P$, Hasan D, H WU. Faktor-Faktor yang Berkaitan/ Berhubungan dengan Medication Error dan Pengaruhnya Terhadap Patient Safety yang Rawat Inap di RS. Pondok Indah - Jakarta Tahun 2012-2015. Fak Farm Univ 17 Agustus 1945 Jakarta. 2017;2(1):1-9. 